Vol. 18 (2009): 57-75.

\title{
Waste composts as nitrogen fertilizers for forage leys
}

\author{
Tiina Tontti*, Arja Nykänen and Miia Kuisma \\ MTT Agrifood Research Finland, Plant Production Research, Lönnrotinkatu 3, FI-50100 Mikkeli, Finland, \\ *email: tiina.tontti@mtt.fi
}

\begin{abstract}
Two field experiments, conventional grass ley and organic grass-clover ley, were established with barley as a nurse crop in spring 2000 and given either low or high fertilization with mineral fertilizer (Mineral) or composts. The compost types were municipal biowaste (Biowaste), biowaste + sewage sludge (BioSludge) and cattle manure (Manure). Plant yields and nitrogen $(\mathrm{N})$ uptakes were measured for three years and efficiency of $\mathrm{N}$ utilization was estimated. In single application of compost, the total $\mathrm{N}$ was mainly in organic form and less than $10 \%$ was in inorganic form. Along with increasing amount of inorganic $\mathrm{N}$ applied in compost, the yield, $\mathrm{N}$ uptake and $\mathrm{N}$ recovery increased during the application year. The highest compost $\mathrm{N}$ recovery in the application year was $12 \%$, found with Biowaste. In the following years the highest $\mathrm{N}$ recovery was found where the lowest total $\mathrm{N}$ had been applied. Clover performance was improved in the organic grass-clover ley established with BioSludge fertilization, producing total ley yield comparable with Manure compost. High total $\mathrm{N}$ application in composts caused high $\mathrm{N}$ surplus and low $\mathrm{N}$ use efficiency over three years. Generally, moderate compost fertilization is suitable for ley crops when supplemented with mineral $\mathrm{N}$ fertilizer or clover $\mathrm{N}$ fixation.
\end{abstract}

Key-words: compost, biowaste, sewage sludge, yield, $\mathrm{N}$ uptake, $\mathrm{N}$ recovery, apparent bio-available N, N balance, $\mathrm{N}$ use efficiency

\section{Introduction}

High amounts of organic waste are produced in municipalities. Both from the ecological and economic point of view the valuable resources in organic waste should be recycled in a sustainable way, and composting is an efficient stabilizing method for treating the organic waste materials (Epstein 1997). Although the quality of waste composts has continuously improved and the contents of heavy metals and pathogens are decreasing and restricted, there are still many challenges for utilizing waste composts in agriculture. Such challenges include 


\section{AGRICULTURAL AND FOOD SCIENCE}

Tontti, T. et al. Waste composts as fertilizers

public acceptance, problems of integration into agricultural practices, quality control, logistics and organization, as well as environmental regulations, economic viability and sustainability (Westerman and Bicudo 2005).

The potential beneficial effects of compost application on fields include increased organic matter, total nitrogen $(\mathrm{N})$ and humus contents of soil. In addition, soil enzyme activities, water-holding capacity, soil structure and plant nutrient supply may be improved by compost applications (Jakobsen 1995, Debosz et al. 2002, Hartl and Erhart 2005). Waste composts include significant amounts of nutrients and the amount of total $\mathrm{N}$ in composts produced from source-separated municipal biowaste can be up to $20 \mathrm{~g} \mathrm{~kg}^{-1}$ on dry weight basis (Houot et al. 2002, Erhart et al. 2005). Comparable Finnish biowaste composts which were matured over 6 months have been found to include 9-20 g total $\mathrm{N} \mathrm{kg}^{-1}$ in dry matter and 2.6-4.1 $\mathrm{g}$ total $\mathrm{P} \mathrm{kg}^{-1}$ in dry matter (Hänninen and Mäkelä-Kurtto 1995). It has been estimated that the nutrients returned to agricultural soil in organic waste could replace about $17 \%$ of the nutrients annually applied to soil with inorganic fertilizers in Finnish food production (Antikainen et al. 2005).

The plant availability of $\mathrm{N}$ from waste composts is generally low since the majority of total $\mathrm{N}$ is in organic form and the mineralization from compost products is usually slow. Various other factors, too, such as compost quality (influenced by origin and processing of waste), climate, soil properties and management as well as $\mathrm{N}$ uptake by the crop, affect the $\mathrm{N}$ dynamics in compost-amended soil (Amlinger et al. 2003). The mineralization of $\mathrm{N}$ is highest during the first year after compost application, but even then the plant $\mathrm{N}$ uptake from biowaste compost is usually below $15 \%$ of the total $\mathrm{N}$ content in compost. During the subsequent years, approximately $2-8 \%$ of the total $\mathrm{N}$ in compost is available to plants per year (Gagnon et al. 1997, Smith et al. 1998, Amlinger et al. 2003). However, the Finnish implementation of the EU nitrate directive 91/676/ EEC (Council of State 931/2000) may limit the amounts of $\mathrm{N}$ applied to agricultural fields to 170 $\mathrm{kg} \mathrm{ha}^{-1}$ total $\mathrm{N}$. If this limit of total $\mathrm{N}$ application were considered to cover compost fertilization as such, it might result with less than $30 \mathrm{~kg} \mathrm{~N}$ in crop uptake, with no possibility for mineral $\mathrm{N}$ addition during the first year.

The agronomic value of waste composts depends highly on their ability to increase the crop yields, whereas from the environmental point of view the quality of waste composts should be high enough to avoid potential harmful effects and rather to improve the quality of soil, plants and environment (Stratton et al. 1995, Amlinger at al. 2003). Composting municipal organic waste together with sewage sludge (i.e. biosolids) can be a way of optimizing the composting process and of improving the product quality, especially by increasing the nutrient contents in compost (Tognetti et al. 2007). In high-quality composts the contents of harmful elements, such as heavy metals, pathogens and toxic organic compounds, are very low or absent, and the application rates could be determined by matching the plant-available $\mathrm{N}$ from the waste compost with the N requirements of crop (Mamo et al. 1999, Amlinger et al. 2003). However, this may require high amounts of applied compost and could lead to salt or heavy metal accumulation and thus to reduced soil quality. Therefore, combination of low amendment rates of composts with sufficient mineral fertilizer has been suggested as an advisable method to meet the crop N requirements (Gagnon et al. 1997, Sullivan et al. 2002). Another approach could be to include legumes in crop rotation and thus to utilize their ability to fix atmospheric $\mathrm{N}$ (Lynch et al. 2004).

Difficulties in predicting the $\mathrm{N}$ supply from composts may limit their routine use in crop production. A number of methods have been developed for estimating the $\mathrm{N}$ availability, but there is no standard method for doing this. Nutrient dynamics in complex soil-plant systems could be formulated with modelling, based on extensive data sets (Gabrielle et al. 2005). More simply, the plant-available $\mathrm{N}$ from the applied fertilizer could be calculated based on crop $\mathrm{N}$ uptakes with inorganic $\mathrm{N}$ contents of soil included in the assessment (Iglesias-Jimenez and Alvarez 1993). Alternatively, the utilization of $\mathrm{N}$ could be estimated based on crop N uptakes only (Lynch et al. 2004, Hartl and Erhart 2005). In the latter two methods the ferti- 


\section{AGRICULTURAL AND FOOD SCIENCE}

Vol. 18 (2009): 57-75.

lized crop may be compared with the unfertilized crop, but potential losses of $\mathrm{N}$ by denitrification, leaching or volatilization and the $\mathrm{N}$ remaining in plant roots are usually excluded.

In order to achieve a balance between inputs and outputs of nutrients, nutrient budgets have been used as a tool to improve nutrient management over periods longer than one growing period within organic farming systems (Watson et al. 2002). Determining $\mathrm{N}$ use efficiency (NUE) is another way of measuring the utilization of applied $\mathrm{N}$ and may be calculated as a ratio between crop $\mathrm{N}$ uptake and applied fertilizer $\mathrm{N}$, i.e. the ratio between outputs and inputs in a cropping system (Cassman et al. 2002).

The application of waste-based composts has been relatively uncommon in Finland, and research has merely focused on processing waste materials, including source-separated biowaste or various sludges from forest industry waste water or sewage water treatment plants (Jokinen 1990, Rantala et al. 1999, Venelampi et al. 2003). In some previous studies, also the quality of composts produced in open-air windrow composting systems has been considered in terms of their final application (Hänninen and Mäkelä-Kurtto 1995, Koivula et al. 2000, Hänninen et al. 2001).

The aim of this study was to test waste composts made of municipal biowaste and sewage sludge as fertilizers for ley production in conventional and organic cropping systems. Specifically, the aim was to define the effect of two levels of waste compost on crop yield and $\mathrm{N}$ uptake over three subsequent years and to estimate the utilization and efficiency of $\mathrm{N}$ by various methods.

\section{Material and methods}

\section{Experiments and fertilizations}

Two field experiments were established in 2000, a conventionally cultivated grass experiment in Mikkeli $\left(61^{\circ} 40^{\prime} \mathrm{N}, 27^{\circ} 13^{\prime} \mathrm{E}\right)$ and an organically cultivated grass-clover experiment in Juva (61 ${ }^{\circ} 53^{\prime}$ $\mathrm{N}, 27^{\circ} 53^{\prime} \mathrm{E}$ ). The soil characteristics in Mikkeli were medium fine sand, $\mathrm{pH}_{\mathrm{H} 2 \mathrm{O}} 6.1$, organic $\mathrm{C} 5.6 \%$, total P $1.1 \mathrm{~g} \mathrm{~kg}^{-1}$ soil, $\mathrm{P}_{\text {AAAc-extractable }} 8.8 \mathrm{mg} \mathrm{l}^{-1}$ soil (class "satisfactory" according to the Finnish soil classification), those in Juva were fine sandy moraine, $\mathrm{pH}_{\mathrm{H} 2 \mathrm{O}} 6.6$, organic $\mathrm{C} 3.0 \%$, total $\mathrm{P} 1.6 \mathrm{~g} \mathrm{~kg}^{-1}$ soil, $\mathrm{P}_{\text {AAAc-extractable }} 20.4 \mathrm{mg} \mathrm{l}^{-1}$ soil (class "good"). The experimental sites were situated $45 \mathrm{~km}$ apart and the climatic data from Mikkeli represent the weather conditions in Juva reasonably well (Table 1). Precipitation was monitored on field in Mikkeli and mean temperatures were obtained from the observation station of the Finnish Meteorological Institute $1 \mathrm{~km}$ away from the grass experiment.

The grass experiment was sown with timothy (Phleum pratense, L., $10 \mathrm{~kg} \mathrm{ha}^{-1}$ ) and meadow fescue (Festuca pratensis, Huds., $15 \mathrm{~kg} \mathrm{ha}^{-1}$ ) with spring barley (Hordeum vulgare, L., 350 seeds $\mathrm{m}^{-2}$ ) as nurse crop. The grass-clover experiment

Table 1. Weather conditions in Mikkeli during the experiments and in the reference period 1961-1990.

\begin{tabular}{|c|c|c|c|c|c|c|c|c|}
\hline & \multicolumn{4}{|c|}{ Precipitation, $\mathrm{mm}^{(1)}$} & \multicolumn{4}{|c|}{ Mean temperature, ${ }^{\circ} \mathrm{C}^{(2)}$} \\
\hline & $\begin{array}{c}\text { average } \\
1961-1990\end{array}$ & 2000 & 2001 & 2002 & $\begin{array}{c}\text { average } \\
1961-1990\end{array}$ & 2000 & 2001 & 2002 \\
\hline May & 40 & 32 & 47 & 48 & 9.4 & 9.3 & 8.0 & 10.8 \\
\hline June & 55 & 75 & 115 & 92 & 14.4 & 13.8 & 13.6 & 15.3 \\
\hline July & 68 & 92 & 120 & 79 & 16.1 & 16.3 & 19.0 & 18.4 \\
\hline August & 88 & 66 & 39 & 19 & 14.1 & 13.8 & 14.1 & 16.6 \\
\hline September & 68 & 22 & 60 & 21 & 8.8 & 7.6 & 10.3 & 8.5 \\
\hline
\end{tabular}

${ }^{(1)}$ Monitored at the research station. ${ }^{(2)}$ From the Finnish Meteorological Institute. 


\section{AGRICULTURAL AND FOOD SCIENCE}

\section{Tontti, T. et al. Waste composts as fertilizers}

was sown with red clover (Trifolium pratense, L.), timothy and meadow fescue (seed rates 5, 8 and 12 $\mathrm{kg} \mathrm{ha}^{-1}$, respectively), with spring barley as nurse crop (350 seeds $\mathrm{m}^{-2}$ ). In both experiments, barley nurse crop was grown in 2000 and forage ley in 2001 and 2002.

The experimental set-up was split-plot design, with two application rates in the main plot (low/ high), fertilizer types in the sub-plot and an unfertilized control treatment at the main plot level. Four replications for each treatment were used and the plot size was $3 \mathrm{~m} \times 10 \mathrm{~m}$ with a $1.5 \mathrm{~m} \times 7 \mathrm{~m}$ harvesting and sampling area within the plot.

The fertilizer types in the grass experiment were mineral NPK fertilizer (Mineral), municipal source-separated biowaste compost (Biowaste) and co-composted municipal source-separated biowaste and municipal anaerobically digested sewage sludge (BioSludge). Accordingly, in the grass-clover experiment the fertilizer types were cattle manure compost (Manure), Biowaste and BioSludge. The Manure was produced by a farmer by composting cattle manure with $1 / 2$ of straw by volume. The BioSludge consisted of approximately $1 / 3$ biowaste and $2 / 3$ sludge. The co-operating composting facilities applied a static, aerated tunnel technique for Biowaste and BioSludge. The compost producers selected good-quality compost batches of adequate maturity (aimed at over 6 months processing) and sieved the material for the experiments (Table 2).

The composts were applied on soil surface in May 2000 and mixed with the upper soil layer (within $0-10 \mathrm{~cm}$ ) by harrowing immediately. The application rates of compost aimed to satisfy the plant $\mathrm{P}$ requirement for two (low application) or four (high application) years, leading to variable $\mathrm{N}$ inputs into the soil in 2000 (Table 2). In the conventional grass experiment, the applications of Biowaste were 20 and $40 \mathrm{Mg} \mathrm{ha}^{-1}$ and those of BioSludge were 22 and $44 \mathrm{Mg} \mathrm{ha}^{-1}$ fresh matter for low and high application, respectively. For the Mineral plots, the nutrients were given according to fertilization recommendations (Table 2). In the organic grass-clover experiment, the applications of Manure were 17 and $33 \mathrm{Mg} \mathrm{ha}^{-1}$, those of Biowaste 23 and $45 \mathrm{Mg} \mathrm{ha}^{-1}$ and of BioSludge 9 and 18 $\mathrm{Mg} \mathrm{ha}^{-1}$ for low and high application, respectively.
For the conventional grass ley in 2001 and 2002, mineral N (250 kg ha-1 year-1) and K (130-160 kg ha $^{-1}$ year $\left.{ }^{-1}\right)$ were supplied for all the treated plots (excluding the unfertilized control), aiming to describe the fertilization practice of a conventional farm. In the organic experiment, no external fertilization was applied after compost application, apart from the input of $\mathrm{N}$ fixation by red clover.

\section{Sampling and analyses}

Compost samples were taken just before the application, with 10 sub-samples collected and mixed thoroughly. Final samples of 1 litre were taken from these and stored frozen.

Crop yields were measured from the $10.5 \mathrm{~m}^{2}$ area at harvesting and plant samples were collected for further analysis; total yield of barley grain and a minimum of $1 \mathrm{~kg}$ of barley straw and leys. Due to weak establishment of the barley nurse crop in the conventional experiment, the plant growth was harvested as a whole crop silage in late July. After that the grass was cut once in late September 2000. Both fractions were combined in the total yield of the conventional experiment in 2000. In the organic experiment the cereal nurse crop was threshed at the end of August 2000. During the subsequent two years the conventional grass ley was cut three times and the organic grass-clover ley twice a year at silage stage. The plant samples from the organic ley were sorted to separate grasses and clover and weighed for determination of clover content of the yield. The plant samples were dried at $60{ }^{\circ} \mathrm{C}$, weighed for dry matter and ground for the analysis of total N.

Soil samples were taken before the establishment of the experiments and thereafter every autumn (September) and spring (May). Composite soil samples were collected with a soil drill from the plough layer (approximately $0-20 \mathrm{~cm}$ deep) of 10-15 systematically chosen points and mixed. A final sample of $0.75 \mathrm{dm}^{3}$ was taken from the mixture and stored frozen.

Ammonium $\left(\mathrm{NH}_{4}^{+}{ }^{-} \mathrm{N}\right)$ and nitrate $\left(\mathrm{NO}_{3}{ }^{-} \mathrm{-N}\right)$ contents of the composts and soil were determined 
Vol. 18 (2009): 57-75.

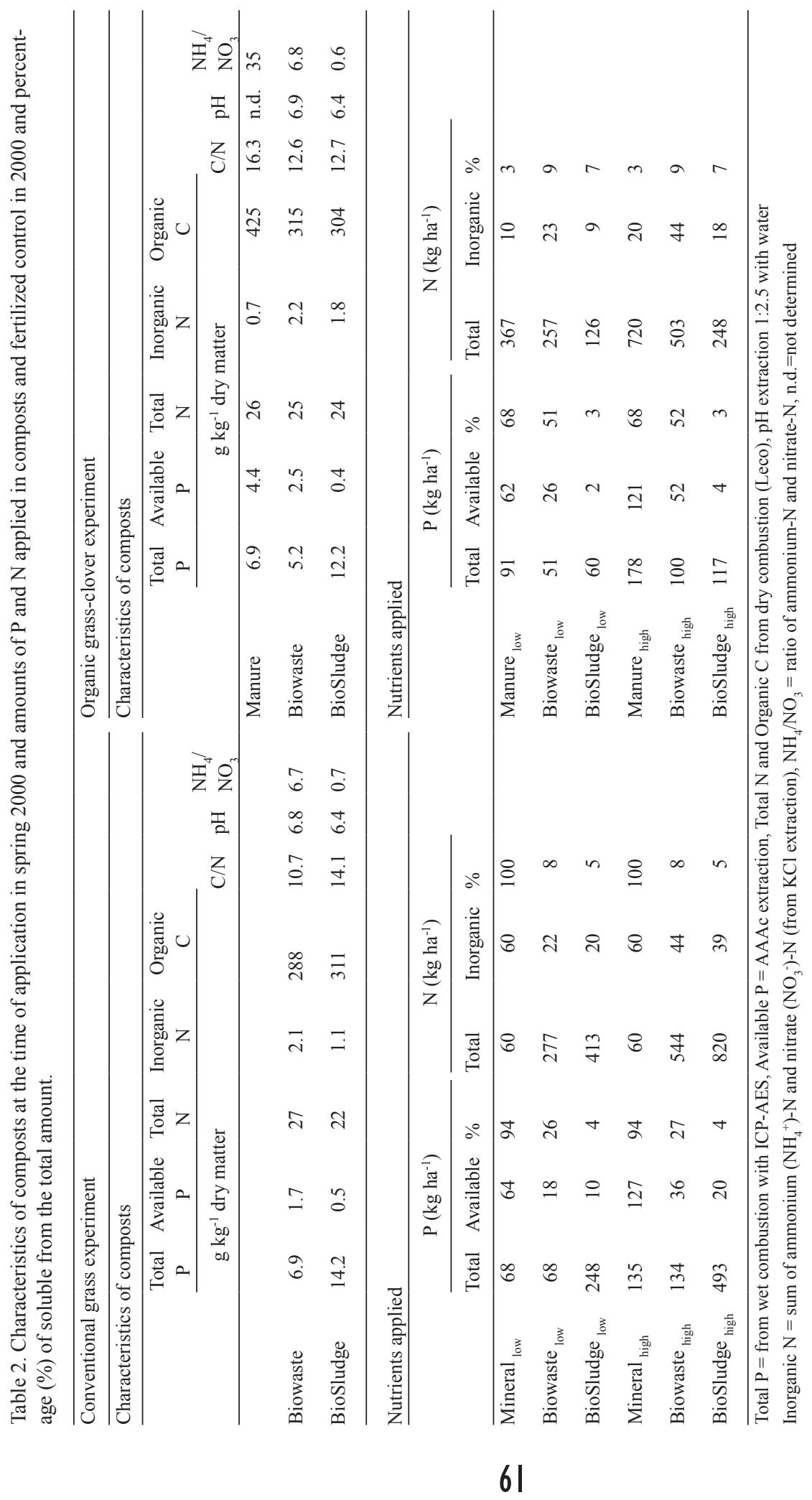




\section{AGRICULTURAL AND FOOD SCIENCE}

Tontti, T. et al. Waste composts as fertilizers

from thawed samples extracted with $2 \mathrm{M} \mathrm{KCl}$ (extraction ratio 1:2.5 by volume) and analyzed spectrophotometrically (Mulvaney 1996). The compost samples were air-dried and ground to pass a 2-mm sieve and analyzed for total $\mathrm{N}$ and $\mathrm{C}$ content by the dry combustion method (Leco CN-2000 analyzer). For total $\mathrm{P}$ content in the composts, wet combustion (nitric acid) and determination with ICP-AES were applied (Agricultural Research Centre of Finland 1986). The soluble $P$ in composts was extracted with acidic ammonium acetate (extraction ratio $1: 10$ by volume, $\mathrm{pH} 4.65$ ) and determined photometrically by the molybdenum blue method (Agricultural Research Centre of Finland 1986). The $\mathrm{N}$ content of plant samples was analyzed by using the dry combustion method (Leco CN-2000 analyzer).

\section{Calculations and definitions}

The $\mathrm{N}$ uptake was calculated as a product of dry matter (DM) yield of harvested plants and $\mathrm{N}$ concentration of the plant sample, while the amount of $\mathrm{N}$ in roots and stubble was not included. For the organic experiment, the $\mathrm{N}$ uptake of grass and clover were calculated separately.

The utilization of fertilizer $\mathrm{N}$ was described by estimating the additional $\mathrm{N}$ uptake (ANU) on annual basis by subtracting the $\mathrm{N}$ uptake in unfertilized crop from the $\mathrm{N}$ uptake in fertilized crop. For the first year, the estimated ANU from fertilizer was assumed to consist of two components, the amount of inorganic $\mathrm{N}$ applied in spring in compost and the rest of ANU representing an estimate of $\mathrm{N}$ released from organic matter $(\mathrm{OM})$ in soil $\left(\mathrm{ANU}_{\mathrm{OM}}\right)$ during the growing period. Thus, the $\mathrm{ANU}_{\mathrm{OM}}$ in soil was estimated by subtracting the amount of inorganic $\mathrm{N}$ in applied compost (see Table 2) from the total ANU. Due to a single compost application, the $\mathrm{ANU}_{\mathrm{OM}}$ was calculated only for the first year.

The efficiency of fertilizer $\mathrm{N}$ utilization was estimated with two equations, $\mathrm{N}$ recovery and apparent bioavailable $\mathrm{N}$ (ABN). The $\mathrm{N}$ recovery describes the proportion of fertilizer $\mathrm{N}$ utilized by plants (i.e. ANU) to the applied amount of fertilizer $\mathrm{N}$. The $\mathrm{N}$ recovery was calculated annually according to Eq. (1) (Iglesias-Jimenez and Alvarez 1993, Hartl and Erhart 2005):
Eq. (1)

$\mathrm{N}$ recovery $\%=\left(\left(\mathrm{NU}_{\mathrm{p}}-\mathrm{NU}_{\mathrm{c}}\right) / \mathrm{N}_{\mathrm{f}}\right) \times 100$

where $\mathrm{NU}_{\mathrm{p}}$ is the total plant $\mathrm{N}$ uptake, $\mathrm{NU}_{\mathrm{c}}$ is the $\mathrm{N}$ uptake by the unfertilized control and $\mathrm{N}_{\mathrm{f}}$ is the total $\mathrm{N}$ applied in fertilizer.

The ABN describes the amount of fertilizer $\mathrm{N}$ utilized by plants and available inorganic $\mathrm{N}$ in soil in relation to the applied $\mathrm{N}$ amount. $\mathrm{ABN}$ was estimated annually according to Eq. (2) (IglesiasJimenez and Alvarez 1993):

Eq. (2)

$\mathrm{ABN} \%=\left(\left(\mathrm{NU}_{\mathrm{p}}+\mathrm{NS}_{\mathrm{s}}-\mathrm{NU}_{\mathrm{c}}-\mathrm{NS}_{\mathrm{c}}\right) / \mathrm{N}_{\mathrm{f}}\right) \times 100$

where $\mathrm{NU}_{\mathrm{p}}$ is the total plant $\mathrm{N}$ uptake, $\mathrm{NS}_{\mathrm{s}}$ is the inorganic $\mathrm{N}$ in soil as determined from the plough layer in autumn, $\mathrm{NU}_{\mathrm{c}}$ is the $\mathrm{N}$ uptake in the unfertilized control, assumed to be equivalent to the $\mathrm{N}$ uptake derived from soil reserve, $\mathrm{NS}_{\mathrm{c}}$ is the inorganic $\mathrm{N}$ in the control plot as determined from the plough layer, assumed to be equivalent to inorganic $\mathrm{N}$ derived from the soil reserve, and $\mathrm{N}_{\mathrm{f}}$ is the total $\mathrm{N}$ applied in the fertilizer.

In the estimates of $\mathrm{N}$ utilization and efficiency, $\mathrm{N}$ uptakes from all the cuts of the growing period were summarized. When estimating $\mathrm{ABN}$, the concentrations of inorganic $\mathrm{N}$ in soil were calculated as a sum of $\mathrm{NH}_{4}^{+}-\mathrm{N}$ and $\mathrm{NO}_{3}^{-}-\mathrm{N}$ in the soil plough layer in autumn. In the $\mathrm{N}$ efficiency estimates for the second and third year it was assumed that total $\mathrm{N}$ previously added in fertilizer and unused by the previous crops was available for plants in soil during the following year. Thus, for the second and third year the annual amount of $\mathrm{N}$ supply $\left(\mathrm{N}_{\mathrm{f}}\right)$ was considered to consist of two components: 1) annually added external $\mathrm{N}\left(\mathrm{N}_{\mathrm{f} \text {-Annual }}\right)$ and 2) previously added total $\mathrm{N}$ that was not found in the uptake of the previous crop $\left(\mathrm{N}_{\text {f-Remains }}\right)$.

In order to estimate atmospheric $\mathrm{N}$ input to the grass-clover ley in 2001 and 2002, the biological $\mathrm{N}_{2}$ fixation (BNF) was estimated by Eq. (3), based on a practical model of BNF estimation developed for farm application (Väisänen 2000, Väisänen et al. 2000): 


\section{AGRICULTURAL AND FOOD SCIENCE}

Vol. 18 (2009): 57-75.

Eq. (3)

$\operatorname{BNF}\left(\mathrm{kg} \mathrm{ha}^{-1}\right)=$

$($ clover $\mathrm{N}(\%) \times$ clover yield $(\mathrm{kg} \mathrm{DM} \mathrm{ha-1}))-$ $\left(0.268 \times\right.$ soil $\mathrm{NO}_{3-}-\mathrm{N}_{\text {spring }}$ content $\left.\left(\mathrm{kgN} \mathrm{ha}^{-1}\right)\right)$

According to these calculations the estimated $\mathrm{BNF}$ was equal to the corresponding clover $\mathrm{N}$ uptake, because soil $\mathrm{NO}_{3}{ }^{-}-\mathrm{N}$ was very low and the effect on BNF estimate was negligible in this experiment.

In the grass-clover ley during the second and third year, the $\mathrm{N}$ uptakes consisted of grass $\mathrm{N}$ uptake and clover $\mathrm{N}$ uptake, while the annually added external $\mathrm{N}\left(\mathrm{N}_{\mathrm{f}-\text { Annual }}\right)$ consisted of "fertilized BNF - unfertilized BNF". Thus, we could formulate Eq. (1) for the grass-clover ley (GC) as:

Eq. (4)

$\mathrm{N}$ recovery $\%_{\mathrm{GC}}=$

$$
\frac{\left(\mathrm{NU}_{\mathrm{p} \text {-Grass }}+\mathrm{NU}_{\mathrm{p} \text {-Clover }}\right)-\left(\mathrm{NU}_{\mathrm{c} \text {-Grass }}+\mathrm{NU}_{\mathrm{c} \text {-Clover }}\right)}{\mathrm{N}_{\mathrm{f} \text {-Remains }}+\mathrm{BNF} F_{\text {fertilized }}-\mathrm{BNF}_{\text {unfertilized }}} \times 100
$$

Because the BNF estimated in the grass-clover ley was equal to the corresponding clover $\mathrm{N}$ uptake during the second and third year, factors $\mathrm{NU}_{\text {p-Clover? }}$ $\mathrm{BNF}_{\text {fertilized }}, \mathrm{NU}_{\mathrm{c}-\text { Clover }}$ and $\mathrm{BNF}_{\text {unfertilized }}$ could be reduced from the equation and the $\mathrm{N}$ recovery in grass of the grass-clover ley was estimated as:

Eq.(5)

$\mathrm{N}$ recovery $\%_{\mathrm{GC}-\mathrm{g}}=$

$$
\frac{\left(\mathrm{NU}_{\mathrm{p} \text {-Grass }}-\mathrm{NU}_{\mathrm{c} \text {-Grass }}\right)}{\mathrm{N}_{\mathrm{f} \text {-Remains }}} \times 100
$$

Corresponding development and reductions could be made for the basic equation of $\mathrm{ABN}$ (Eq. 2 ), resulting with an estimate of $A B N$ in grass of the grass-clover ley as:

$$
\begin{aligned}
& \text { Eq. (6) } \\
& \begin{array}{l}
\mathrm{ABN} \%_{\mathrm{GC}-\mathrm{g}} \\
\frac{\mathrm{NU}_{\mathrm{p}-\text { Grass }}+\mathrm{NS}_{\mathrm{s}}-\mathrm{NU}_{\mathrm{c} \text {-Grass }}-\mathrm{NS}_{\mathrm{c}}}{\mathrm{N}_{\mathrm{f} \text {-Remains }}} \times 100
\end{array}
\end{aligned}
$$

The $\mathrm{N}$ balance was calculated for the total three-year period in both experiments as a difference between total $\mathrm{N}$ input and total $\mathrm{N}$ output. The $\mathrm{N}$ input consisted of total $\mathrm{N}$ added in fertilizer and of estimated $\mathrm{N}$ fixation of clover, while output equalled the $\mathrm{N}$ uptake in the harvested crop. The $\mathrm{N}$ use efficiency (NUE) was calculated as a percentage of the ratio between total $\mathrm{N}$ output and $\mathrm{N}$ input over a three-year period (Watson et al. 2002).

\section{Statistical analyses}

The experimental design was a split-plot design where the main-plot treatments (application rate) were in a randomized complete-block design and the sub-plot treatments (compost type) were randomized within each main plot. Consequently, the statistical analyses of the annual data were based on the common mixed model for a split-plot design which included three fixed effects (application rate, compost type and their interaction) and three random effects (block, main-plot error and sub-plot error) (Littell et al. 2006). The analyses were performed using the SAS system for Windows, version 9.1.3 and the SAS Enterprise Guide, version 4.1 (SAS Institute Inc., Cary, NC, USA). Pairwise comparisons were made using two-sided t-type tests. Model assumptions were checked by graphs of residuals. REML was used as an estimation method and degrees of freedom were calculated using the containment method or the Kenward-Roger method (Kenward and Roger 1997). In order to minimize the number of plots, the unfertilized control was randomized only at the main-plot level. Thus the unfertilized control was not included in statistical analyses made according to the split-plot design, and deviations from the unfertilized control were considered visually. In the paired comparisons, only differences within the application rate were considered interesting and compared with each other. This constraint in the number of comparisons helped to minimize type I errors. 
Tontti, T. et al. Waste composts as fertilizers

\section{Results}

\section{Crop yield and $\mathrm{N}$ uptake}

In the first year of the conventional grass experiment, low compost fertilizations produced about $1000 \mathrm{~kg}$ $\mathrm{ha}^{-1}$ lower dry matter yields than the Mineral $_{\text {low }}$ which produced $6600 \mathrm{~kg} \mathrm{ha}^{-1}$ of barley-grass, and plant $\mathrm{N}$ uptakes complied closely with the yield results (Fig. 1). With Mineral ${ }_{\text {low }}$ the $\mathrm{N}$ uptake was $141 \mathrm{~kg}$ $\mathrm{N} \mathrm{ha}^{-1}$, while with Biowaste ${ }_{\text {low }}$ and BioSludge ${ }_{\text {low }}$ the $\mathrm{N}$ uptake was 21 or $29 \mathrm{~kg}$ lower, respectively. Compared with the unfertilized control in the first year, the dry matter yield was 30-35\% higher with low compost fertilization and $47-51 \%$ higher with high compost fertilization. Accordingly, compared with the unfertilized control, the $\mathrm{N}$ uptake was $28-37 \%$ higher with low compost fertilization and $50-58 \%$ higher with high compost fertilization. During the second and third year the dry matter yield of grass ley was generally equal for all fertilized treatments, approximately $12000 \mathrm{~kg} \mathrm{ha}^{-1}$, since equal mineral $\mathrm{N}$ fertilization of $250 \mathrm{~kg} \mathrm{~N}^{-1}$ was applied during these years. However, in the third year, both yield and $\mathrm{N}$ uptake were higher with BioSludge ${ }_{\text {high }}$ compared with Mineral ${ }_{\text {high }}$ (Fig. 1). No significant differences could be found in the yield or $\mathrm{N}$ uptake between high and low fertilization levels in any of these years.

The total biomass and $\mathrm{N}$ uptake in the organic spring barley nurse crop was higher with Biowaste than with BioSludge and Manure composts $(p<0.01)$. The average biomass with Biowaste, BioSludge and Manure fertilization was 4150, 3560 and $3480 \mathrm{~kg} \mathrm{DM} \mathrm{ha}^{-1}$ and the average $\mathrm{N}$ uptake was 69,53 and $60 \mathrm{~kg} \mathrm{~N} \mathrm{ha}^{-1}$, respectively. The total biomass of unfertilized barley nurse crop was 2620 $\mathrm{kg} \mathrm{DM} \mathrm{ha}{ }^{-1}$ and the $\mathrm{N}$ uptake was $44 \mathrm{~kg} \mathrm{~N} \mathrm{ha}^{-1}$. The grain yield of the organic barley nurse crop fertilized with Biowaste was higher $(p<0.05)$ than with Manure or with BioSludge compost (average 2670, 2350 and $2170 \mathrm{~kg} \mathrm{DM} \mathrm{ha}^{-1}$, respectively). However, the $\mathrm{N}$ uptake of barley grain fertilized with Biowaste was no different from that with Manure compost (Fig. 2), whereas the $\mathrm{N}$ uptake with BioSludge was lower than that with Biowaste ( $p=0.003$ ), with average $\mathrm{N}$ uptakes of 56,50 and 43 $\mathrm{kg} \mathrm{N} \mathrm{ha}{ }^{-1}$, respectively. The grain yield of unfertilized barley nurse crop was $1630 \mathrm{~kg} \mathrm{DM} \mathrm{ha}^{-1}$ and $\mathrm{N}$ uptake was $32 \mathrm{~kg} \mathrm{~N} \mathrm{ha}^{-1}$.

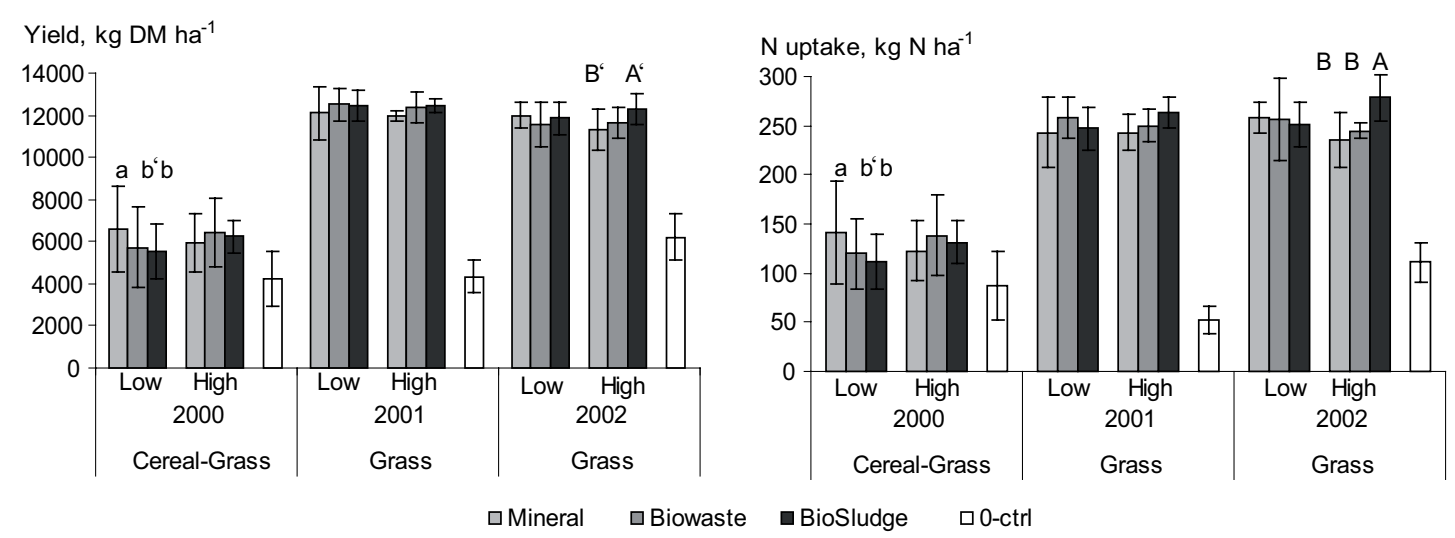

Fig. 1. Total dry matter yield and plant $\mathrm{N}$ uptake in the conventional grass ley experiment. Vertical lines indicate standard deviations of measurement replicates. Means denoted by different letters differ significantly from each other within the low $(\mathrm{a} / \mathrm{b})$ or high application $(\mathrm{A} / \mathrm{B})$ with $p<0.05$. When denoted by ', the difference is marginally significant at $0.05<p<0.10$. $(0$-ctrl $=$ unfertilized control $)$ 
Vol. 18 (2009): 57-75.

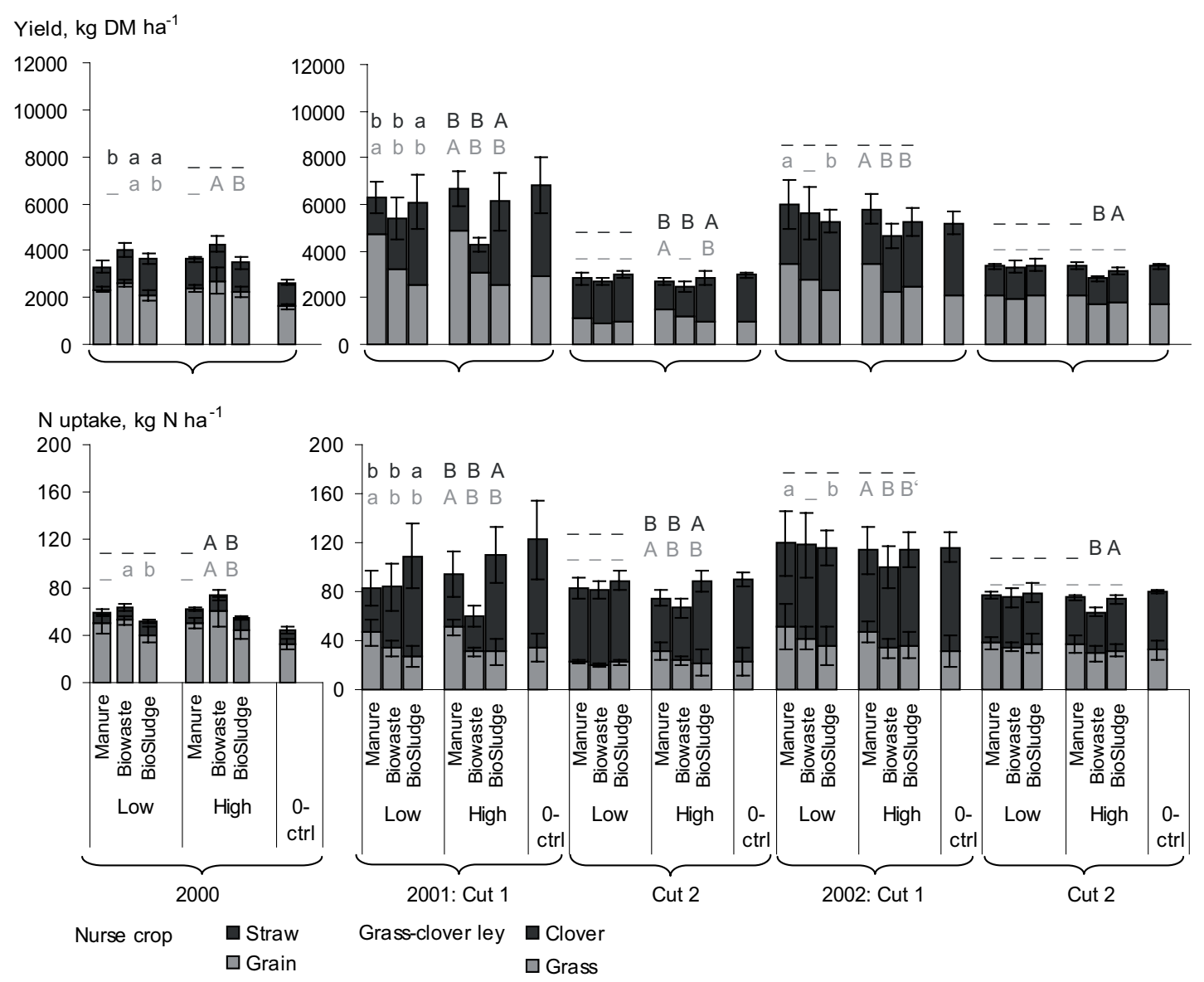

Fig. 2. Yield and N uptake in the barley nurse crop in 2000 and in grass-clover ley in 2001 and 2002 in the organic experiment. Vertical lines indicate standard deviations of measurement replicates. Fertilization means significantly different $(p<0.05)$ from each other within low $(\mathrm{a} / \mathrm{b})$ or high application $(\mathrm{A} / \mathrm{B})$ are marked with differing letters above the bar, with similar colours as in the bars. When denoted by ', the difference is marginally significant at $0.05<p<0.10$. $(0$-ctrl $=$ unfertilized control)

In the second year after the fertilizations, the total biomass in grass-clover ley fertilized with Biowaste was at least $1600 \mathrm{~kg}$ lower and $\mathrm{N}$ uptake about $20 \mathrm{~kg}$ lower when compared with other compost types $(p<0.04)$, averaging $9140 \mathrm{~kg} \mathrm{DM}$ $\mathrm{ha}^{-1}$ and $180 \mathrm{~kg} \mathrm{~N} \mathrm{ha}^{-1}$. On the other hand, the $\mathrm{N}$ uptake with BioSludge was $93 \%$ of that in unfertilized grass-clover ley $\left(213 \mathrm{~kg} \mathrm{~N} \mathrm{ha}^{-1}\right)$ and over $30 \mathrm{~kg}$ higher than with other composts $(p<0.005)$. With Biowaste and Manure the $\mathrm{N}$ uptakes accounted for less than $80 \%$ of the $\mathrm{N}$ uptake in unfertilized grassclover ley. In the third year after fertilizations, the total biomass of grass-clover ley fertilized with Biowaste was still lower than with Manure compost $(p=0.04)$, whereas both biomass and $\mathrm{N}$ uptake with BioSludge and Manure were close to those in the unfertilized grass-clover ley, corresponding to $99-110 \%$ of the biomass and $96-100 \%$ of the $\mathrm{N}$ uptake. 


\section{AGRICULTURAL AND FOOD SCIENCE}

\section{Tontti, T. et al. Waste composts as fertilizers}

In the second and third year the grass-clover ley consisted of two components, grass and clover, which responded differently to compost fertilizations (Fig. 2). The clover yield was higher with BioSludge than with other composts in both cuts of the grass-clover ley in $2001(p<0.002)$, while in the first cut the grass yield with Manure was higher than with Biowaste and BioSludge composts $(p<0.01)$. Similar differences were found also in 2002, with Manure increasing the growth of grass

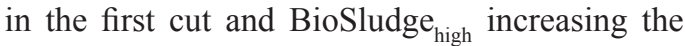
growth of clover in the second cut of grass-clover ley $(p<0.02)$ (Fig. 2).

According to the yield differences in 2001, also $\mathrm{N}$ uptake in clover (i.e. BNF) was higher with BioSludge, and $\mathrm{N}$ uptake in grass was higher with Manure, when compared with other compost fertilizations $(p<0.02)$. In the second year and after low compost fertilization, the estimated BNF was higher than after high fertilization $(p<0.05)$. The BNF with BioSludge was close to that in unfertilized grass-clover ley and higher than with other compost fertilizations $(p<0.001)$, with BNF averaging 147, 90, 91 and $155 \mathrm{~kg} \mathrm{~N} \mathrm{ha}^{-1}$ with BioSludge, Biowaste, Manure and unfertilized control, respectively. In the third year after compost fertilization, the BNF ranged between 105 and $119 \mathrm{~kg} \mathrm{~N} \mathrm{ha}^{-1}$, whereas the BNF in unfertilized grass-clover ley was $130 \mathrm{~kg} \mathrm{~N} \mathrm{ha}^{-1}$. The BNF estimates were equal to the corresponding total annual clover $\mathrm{N}$ uptake amounts, due to a negligible effect of soil $\mathrm{NO}_{3}-\mathrm{N}$ on these estimates.

Generally, both yield and N uptake of grass-clover were similar between low and high fertilization each year and in each crop fraction. The only exception was found in the second cut of 2001, where both yield and $\mathrm{N}$ uptake in clover were higher with low fertilization than with high fertilization.

\section{Additional $N$ uptake}

The ANU describes the annual utilization of fertilizer $\mathrm{N}$ in a more detailed way than $\mathrm{N}$ uptake. In the first year, the ANU of conventional barley-grass with Mineral $_{\text {low }}$ was $54 \mathrm{~kg} \mathrm{~N}$ ha'$^{-1}$, whereas with Biowaste $_{\text {low }}$ and BioSludge ${ }_{\text {low }}$ the ANUs were 22 $\mathrm{kg}$ and $30 \mathrm{~kg}$ lower, respectively (Table 3 ). The estimate of $\mathrm{ANU}_{\mathrm{OM}}$, originating from either compost or soil, remained positive for both waste composts as opposed to the Mineral-fertilized barley-grass $(p<0.05)$ with negative $\mathrm{ANU}_{\mathrm{OM}}$ estimates (Table $3)$. In 2001, the total ANU of grass ley averaged $199 \mathrm{~kg} \mathrm{~N} \mathrm{ha}^{-1}$, whereas in 2002 the ANU of grass averaged $144 \mathrm{~kg} \mathrm{~N} \mathrm{ha}^{-1}$ after low fertilization and after high fertilization ranged from $124 \mathrm{~kg} \mathrm{~N} \mathrm{ha}^{-1}$ up to the highest ANU $168 \mathrm{~kg} \mathrm{~N} \mathrm{ha}^{-1}$ found with BioSludge $_{\text {high }}$.

In the first year the ANU in the organic barley nurse crop fertilized with Biowaste compost was higher than that with Manure and BioSludge $\left(p<0.05\right.$ ), averaging 25,16 and $9 \mathrm{~kg} \mathrm{~N}^{-1}$, respectively (Table 3 ). However, the estimate of $\mathrm{ANU}_{\mathrm{OM}}$ was negative for all treatments, except for Manure $_{\text {low }}$. In the organic grass-clover ley in 2001 and 2002 the ANUs of grass were $12-26 \mathrm{~kg} \mathrm{~N} \mathrm{ha}^{-1}$ when fertilized with Manure, being higher than with other composts $(p<0.05)$. Moreover, the ANUs of clover were clearly negative when fertilized with Manure or Biowaste (Table 3).

In general, the ANU was the same between low and high fertilization in both experiments each year. The only exception was found in the second year, as the ANU of clover was lower with high fertilization than with low fertilization $(p<0.05)$. The negative estimates of $\mathrm{ANU}_{\mathrm{OM}}$ in both experiments indicate that part of inorganic $\mathrm{N}$ added in fertilizers was not utilized by plants and was possibly immobilized in soil or lost through leaching or volatilization. However, part of the negative estimates and particularly the negative values close to zero may be explained by the $\mathrm{N}$ remaining in plant roots and stubble which was not included in the $\mathrm{N}$ uptake. The negative ANUs of the grass-clover ley indicated that in those cases the unfertilized clover or grass yielded better than the fertilized crops.

\section{$N$ recovery and $A B N$}

$\mathrm{N}$ recovery and $\mathrm{ABN}$ estimate the efficiency of fertilizer $\mathrm{N}$ utilization which basically describes the proportion of ANU from the amount of $\mathrm{N}$ supplied in fertilizers into the soil. Throughout the conventional experiment, the $\mathrm{N}$ recovery with compost fertilizations was lower than with Mineral fertilization $(p<0.05)$ (Table 4). For the first year the N recoveries from composts were less than $15 \%$, whereas 


\section{AGRICULTURAL AND FOOD SCIENCE}

Vol. 18 (2009): 57-75.

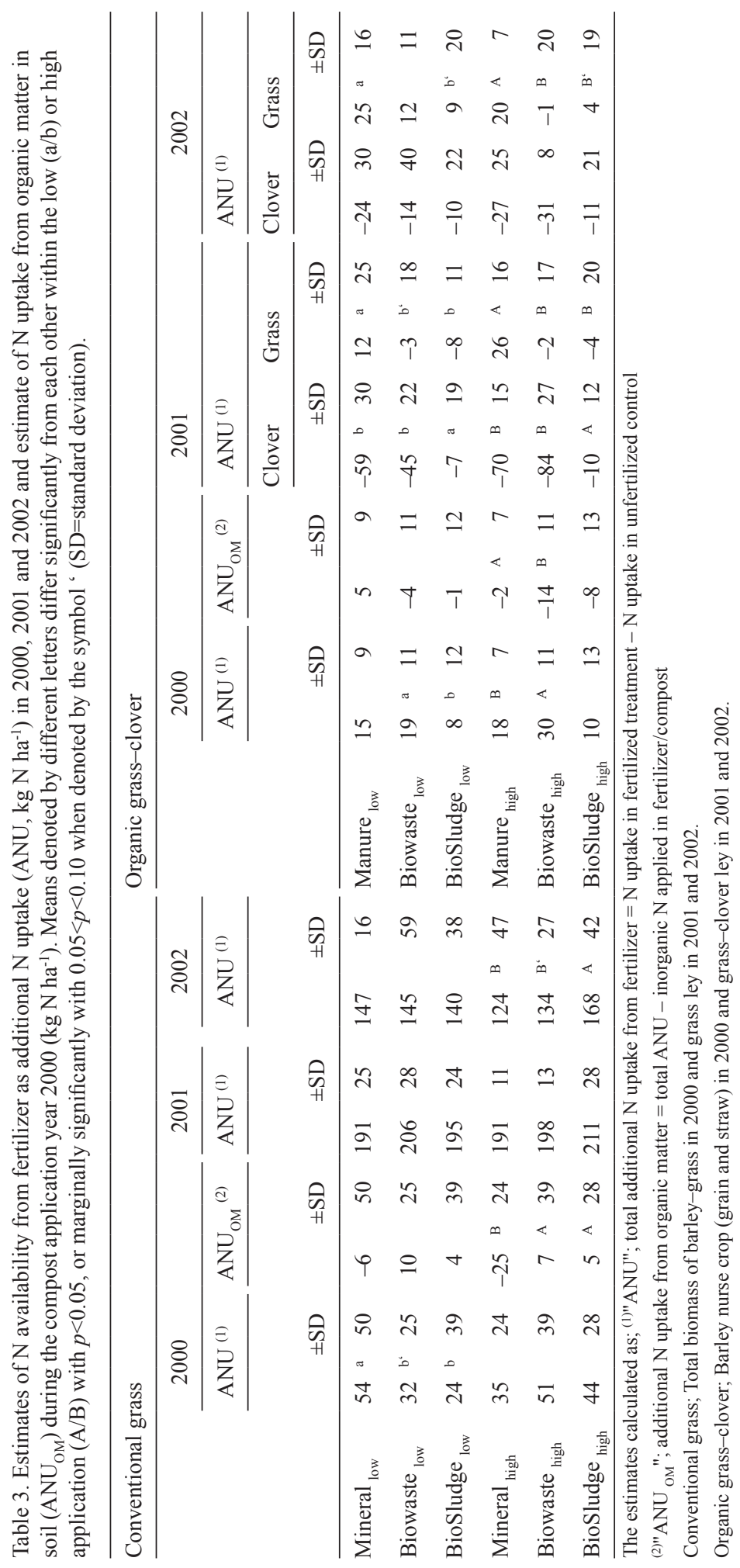




\section{AGRICULTURAL AND FOOD SCIENCE}

Tontti, T. et al. Waste composts as fertilizers

Table 4. Efficiency of applied fertilizer $\mathrm{N}$ estimated with $\mathrm{N}$ recovery (\%) in conventional grass and organic grass-clover ley. Means denoted by different letters differ significantly from each other within the low (a/b) or high application (A/B) with $p<0.05$, or marginally significantly with $0.05<p<0.10$ when denoted by the symbol ' $(\mathrm{SD}=$ standard deviation).

\begin{tabular}{|c|c|c|c|c|c|c|c|c|c|c|c|c|c|c|}
\hline \multicolumn{8}{|c|}{ Conventional grass ${ }^{(1)}$} & \multicolumn{7}{|c|}{ Organic grass-clover ${ }^{(2)}$} \\
\hline & \multicolumn{2}{|c|}{2000} & \multicolumn{2}{|c|}{2001} & \multicolumn{3}{|c|}{2002} & & \multicolumn{2}{|c|}{2000} & \multicolumn{2}{|c|}{2001} & \multicolumn{2}{|c|}{2002} \\
\hline & & $\pm \mathrm{SD}$ & & ESD & & & $\pm \mathrm{SD}$ & & & SD & & $\pm \mathrm{SD}$ & & $\pm \mathrm{SD}$ \\
\hline Mineral $_{\text {low }}$ & $89^{\text {a }}$ & 83 & $75^{a}$ & 9 & 47 & a & 9 & Manure $_{\text {low }}$ & 4 & 2 & $3^{\mathrm{a}}$ & 7 & 7 & 4 \\
\hline Biowaste $_{\text {low }}$ & $12^{b}$ & 9 & $42^{b}$ & 8 & 28 & $\mathrm{~b}$ & 14 & Biowaste $_{\text {low }}$ & 8 & 4 & -1 & 7 & 5 & 5 \\
\hline BioSludge $_{\text {low }}$ & $6^{\mathrm{b}}$ & 9 & $31^{\mathrm{c}}$ & 5 & 21 & $\mathrm{~b}$ & 7 & BioSludge $_{\text {low }}$ & 6 & 9 & $-7^{\mathrm{b}}$ & 10 & 8 & 17 \\
\hline Mineral $_{\text {high }}$ & $58^{\mathrm{A}}$ & 41 & $69 \mathrm{~A}$ & 5 & 38 & A & 15 & Manure $_{\text {high }}$ & 2 & 1 & $4^{\mathrm{A}}$ & 2 & 3 & 1 \\
\hline Biowaste $_{\text {high }}$ & $9^{\mathrm{B}}$ & 7 & 27 B & 3 & 17 & B & 5 & Biowaste $_{\text {high }}$ & 6 & 2 & 0 & 4 & 0 & 4 \\
\hline BioSludge $_{\text {high }}$ & $5^{\text {в }}$ & 4 & $21 \mathrm{c}$ & 3 & 16 & B & 5 & BioSludge $_{\text {high }}$ & 4 & 5 & $-2^{\mathrm{B}^{\prime}}$ & 9 & 2 & 8 \\
\hline
\end{tabular}

The $\mathrm{N}$ recovery estimate $=($ fertilized $\mathrm{N}$ uptake - unfertilized $\mathrm{N}$ uptake $) /$ external $\mathrm{N}$ added and remaining in soil

(1) Total biomass of barley-grass in 2000 and grass ley in 2001 and 2002.

(2) Barley nurse crop (grain + straw) in 2000 and grass fraction of grass-clover ley in 2001 and 2002.

with Mineral fertilization over $55 \%$ of the applied $\mathrm{N}$ was used. In the subsequent years, the average $\mathrm{N}$ recoveries for Mineral, Biowaste and BioSludge were 72,34 and $26 \%$ for the second year and 42 , 23 and $18 \%$ for the third year, respectively. Due to negligible differences in soil inorganic $\mathrm{N}$ contents, the $\mathrm{ABN}$ estimates virtually equalled the $\mathrm{N}$ recovery estimates, being within $\pm 1 \%$ units from each other. Due to equal $\mathrm{N}$ uptakes by plants at both fertilization levels the $\mathrm{N}$ recovery with low fertilization was generally higher, but significantly different from the high fertilization only in the second and third year after compost fertilization $(p<0.05)$.

The $\mathrm{N}$ recovery in the organic barley nurse crop was very low, being within $2-8 \%$ with all compost fertilizations (Table 4). During the second year the highest estimates of $\mathrm{N}$ recovery were $3-4 \%$ found with Manure, where also the ANU was found positive in grass of the organic ley. The negative $\mathrm{N}$ recovery in organic ley indicates that the $\mathrm{N}$ uptake in fertilized grass was lower than in the unfertilized one. Furthermore, when ANU approached zero and the fertilizer- $\mathrm{N}$ supply in soil $\left(\mathrm{N}_{\mathrm{f}-\text { Remains }}\right)$ was substantially high, also the $\mathrm{N}$ recovery approached zero. In the third year, the $\mathrm{N}$ recovery was $8 \%$ at the highest and no significant differences were found. The $\mathrm{ABN}$ estimates virtually equalled the $\mathrm{N}$ recovery in the organic ley as well, since at the highest the $\mathrm{ABN}$ was only $+2 \%$ units from the $\mathrm{N}$ recovery.

\section{$N$ balance and NUE}

The $\mathrm{N}$ balance of conventional grass ley over the three-year period was negative with Mineral fertilization, indicating that part of crop $\mathrm{N}$ was extracted from soil reserves (Fig. 3). In both experiments the $\mathrm{N}$ balance was positive with compost fertilizations, except for BioSludge ${ }_{\text {low }}$. The surplus of $\mathrm{N}$ was higher with higher $\mathrm{N}$ input because the $\mathrm{N}$ output, i.e. $\mathrm{N}$ uptake, remained nearly the same in all treatments in both experiments (Fig. 3). The highest surplus of $\mathrm{N}$ was $650 \mathrm{~kg} \mathrm{~N} \mathrm{ha}^{-1}$ found in the conventional grass, while in the organic grass-clover the highest $\mathrm{N}$ surplus was $490 \mathrm{~kg} \mathrm{~N} \mathrm{ha}^{-1}$.

When $\mathrm{N}$ inputs and $\mathrm{N}$ surplus were higher, the NUEs were obviously decreased, with significant differences between all fertilizations $(p<0.05)$. In the conventional grass, the NUE decreased in the order: Mineral $(111 \%)>$ Biowaste $(71 \%)>$ BioSludge (59\%), in the organic grass-clover in 
Vol. 18 (2009): 57-75.
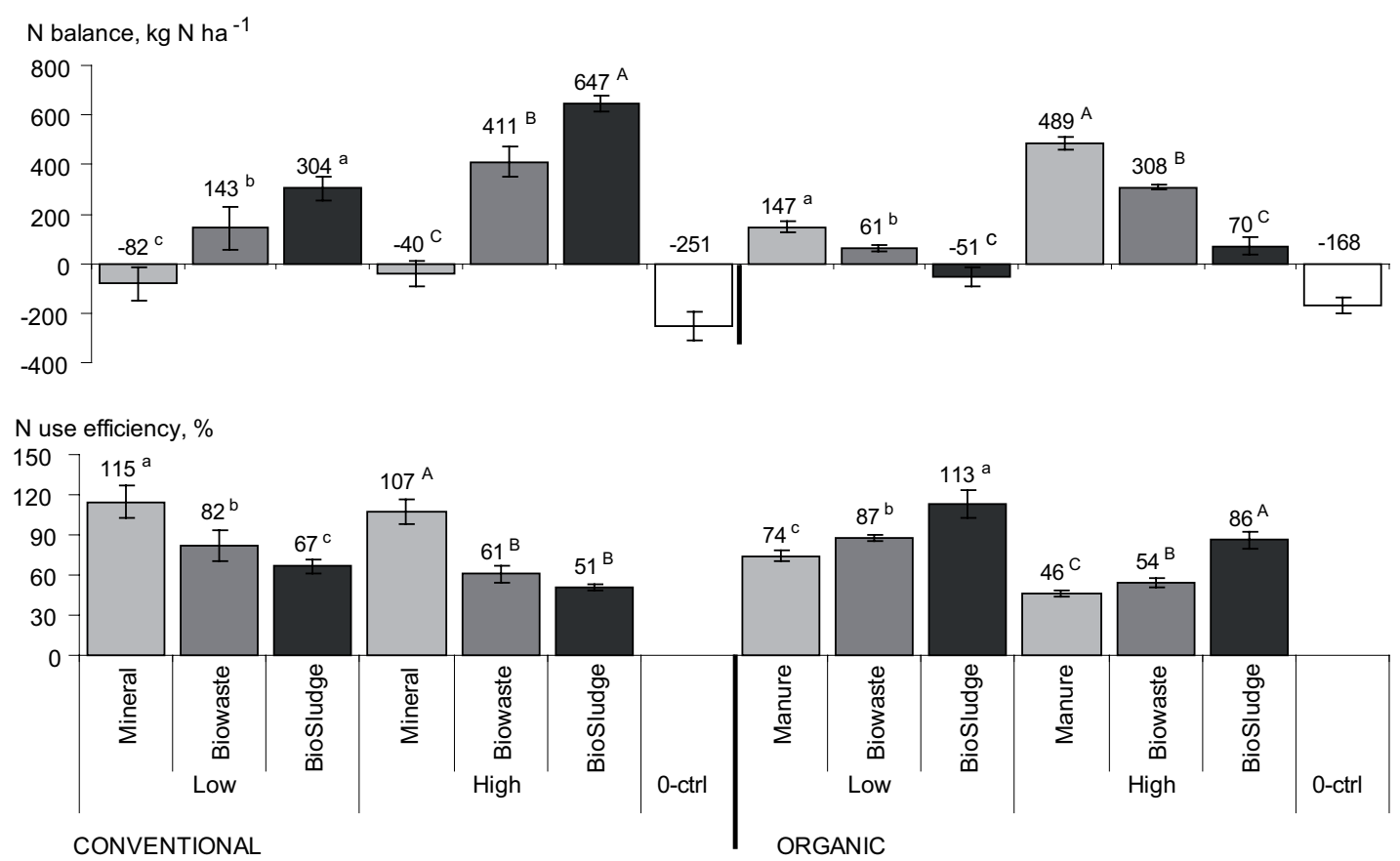

Fig. 3. The $\mathrm{N}$ balance and $\mathrm{N}$ use efficiency (NUE) over a three-year period in the conventional and organic experiment. Estimates were calculated as " $\mathrm{N}$ balance $=\mathrm{N}$ input $-\mathrm{N}$ output" and "NUE\% $=(\mathrm{N}$ output $/ \mathrm{N}$ input $) \times 100$ ". Means denoted by different letters differ significantly from each other within the low $(\mathrm{a} / \mathrm{b} / \mathrm{c})$ or high $(\mathrm{A} / \mathrm{B} / \mathrm{C})$ application, with $p<0.05$. (0-ctrl $=$ unfertilized control)

the order: BioSludge $(100 \%)>$ Biowaste $(71 \%)>$ Manure $(60 \%)$. In both experiments the low fertilization level resulted in better NUE than the high fertilization level $(p<0.05)$.

\section{Discussion}

\section{Yield and $N$ uptake}

The differences in plant $\mathrm{N}$ uptake followed the changes in plant dry matter yield in both experiments, which was observed also in other compost fertilization studies (Gagnon et al. 1997, Lynch et al. 2004). In the first year of the conventional grass experiment, both yield and $\mathrm{N}$ uptake were lower with low compost fertilizations compared with Mineral fertilization, whereas with high compost fertilizations yield and $\mathrm{N}$ uptake did not differ from Mineral. In the organic barley nurse crop, Biowaste produced higher biomass and $\mathrm{N}$ uptake than BioSludge or Manure. According to Svensson et al. (2004) the inorganic $\mathrm{N}$ amount in compost is probably the most important explaining factor for the yield and $\mathrm{N}$ uptake during the application year. In our experiments, less than $10 \%$ of total $\mathrm{N}$ in composts was in inorganic form at the time of application. In the organic experiment the high amount of inorganic $\mathrm{N}$ applied in Biowaste, $45 \mathrm{~kg} \mathrm{ha}^{-1}$ and twice the amount applied in BioSludge and Manure, explained the differences in crop production. Furthermore, equal amounts of inorganic $\mathrm{N}$ applied in Biowaste and 


\section{AGRICULTURAL AND FOOD SCIENCE}

\section{Tontti, T. et al. Waste composts as fertilizers}

BioSludge in the conventional experiment produced equal yields between compost types.

All fertilizations increased yields and $\mathrm{N}$ uptakes compared with the unfertilized control during the first year after application, which was found also when Zheljazkov et al. (2006) fertilized the mixture of timothy and red clover with municipal solid waste compost. Erhart et al. (2005) fertilized winter cereals with biowaste compost and found annual yield increases of less than $30 \%$ compared with the unfertilized control which was mostly lower than the increases of $26-63 \%$ we found. The higher amount of inorganic $\mathrm{N}$ in compost may partly explain our higher increases, and some could be due to applying composts in spring, higher maturity and total $\mathrm{N}$ concentration of compost, or due to moist weather conditions during summer.

These experimental soils were rather fertile with favourable capillary water conditions and the weather conditions during mid-summer were moist with average temperatures, whereas the benefits of compost additions might have become more evident in less favourable growth conditions. Additionally, the variable results of compost fertilization and efficiency of $\mathrm{N}$ utilization between different studies may be caused by different calculation procedures or experimental plants, source of $\mathrm{N}$ addition or fertilization level. The maturity of compost and timing of application may also affect the $\mathrm{N}$ efficiency but apart from that part of $\mathrm{N}$ could be lost and other nutrients than N may affect the crop growth (Fauci and Dick 1994, Sikora and Enkiri 1999, Keeling et al. 2003, Svensson et al. 2004).

In a review of several compost fertilization studies Amlinger et al. (2003) concluded that in general $2-8 \%$ of the total $\mathrm{N}$ in compost remaining in soil after the first year could be used by plants annually in subsequent years. We found the annual $\mathrm{N}$ utilization based on crop production difficult to measure after the application year due to the influence of red clover in the organic system and the mineral $\mathrm{N}$ added in the conventional system. Mineral $\mathrm{N}$ fertilizer was applied according to annual fertilization recommendations for the grass ley in 2001 and 2002 in Finland. The amount was apparently too high when combined with preceding compost additions, since crop production was equal with both fertilization levels. Apparently the added mineral $\mathrm{N}$ fulfilled most of the crop $\mathrm{N}$ requirements, whereas compost $\mathrm{N}$ was not required. A clear difference between the yields with BioSludge high $_{\text {and }}$ Mineral $_{\text {high }}$ was found only in 2002, which could be partly explained by the large amount of total $\mathrm{N}$ applied in BioSludge ${ }_{\text {high }}$ compost, but most likely the difference was due to an unexplained yield decrease with Mineral ${ }_{\text {high }}$.

Red clover has a considerable effect on yield within grass-clover leys. The clover yield increases with decreasing inorganic $\mathrm{N}$ supply in soil, and with increasing inorganic $\mathrm{N}$ amounts grasses are more competitive against clover (Boller and Nösberger 1987). In the study of Lynch et al. (2004), sewage sludge compost produced $\mathrm{N}$ uptakes equal to fertilization with liquid manure, manure compost, corn-silage compost or ammonium nitrate fertilizer applied to clover-timothy mixture. In timothy monoculture fertilized with sewage sludge compost, they found lower $\mathrm{N}$ uptakes. In our organic grassclover ley, the total plant biomass and $\mathrm{N}$ uptake tended to be lower with Biowaste and higher with BioSludge when compared with Manure. The N availability from BioSludge compost was apparently low, since the yields of grass and clover were close to those in the unfertilized control and the clover yield was higher than with other composts.

We found the highest BNF estimates, up to 155 $\mathrm{kg}$, with the lowest amount of compost $\mathrm{N}$ applied. These BNF estimates were higher than the highest BNF $67 \mathrm{~kg} \mathrm{~N} \mathrm{ha}^{-1}$ previously found on active organic farms in Finland. Our estimates were closer to previous BNF estimates of $90-114 \mathrm{~kg} \mathrm{~N}^{-1}$ in experimental fields (Väisänen et al. 2000), although in field-scale BNF in organic grass-clover leys may be also highly variable, ranging from 20

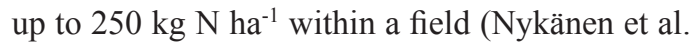
2008). In agreement with our results, Lynch et al. (2004) found that in legume-grass forage fertilized with compost containing a low amount of inorganic $\mathrm{N}$, the BNF was close to the level obtained in unfertilized legume-grass.

\section{Utilization of $N$}

The ANU was generally the same between the two fertilization levels each year, but in the first 


\section{AGRICULTURAL AND FOOD SCIENCE}

Vol. 18 (2009): 57-75.

year the increases of ANU appeared to follow the increases of inorganic $\mathrm{N}$ added in fertilizer. The $\mathrm{ANU}_{\mathrm{OM}}$ estimated for the compost application year remained below $10 \mathrm{~kg} \mathrm{~N} \mathrm{ha}^{-1}$ for all treatments, suggesting rather low mineralization in soil. The negative estimates of $\mathrm{ANU}_{\mathrm{OM}}$ were found when the fertilized ANU was lower than the amount of inorganic $\mathrm{N}$ added in fertilizer, suggesting that part of the inorganic $\mathrm{N}$ applied in fertilizer was not harvested in the crops. In the second and third year after application the negative ANU values found in grass-clover ley were due to high yields in the unfertilized ley. This was particularly evident with ANU of the clover fraction. Accordingly, in previous studies the grass-clover yields in organically managed fields were generally good without additional fertilization (Nykänen et al. 2000). The higher ANU in the grass of Manure-fertilized grass-clover ley compared with other fertilizations reflected increased grass $\mathrm{N}$ uptakes in both cuts with Manure.

The high positive values of $\mathrm{N}$ balance over three years reflected surplus of $\mathrm{N}$ due to the high amount of organic $\mathrm{N}$ applied in composts, whereas the clearly negative $\mathrm{N}$ balances in unfertilized soils indicated shortage of $\mathrm{N}$ in soil. The most preferable balances would be small positive values which were found with Biowaste and low fertilization in both conventional and organic systems. Previously, in organic grass-clover leys with BNF as a sole $\mathrm{N}$ input, the $\mathrm{N}$ balances were mostly negative after two years of cultivation if the yields were removed from the field (Nykänen 2008). There, the conclusion was that the $\mathrm{N}$ input in organic systems should remain higher than $\mathrm{N}$ output in order to maintain positive but not excessively high $\mathrm{N}$ balances.

\section{Efficiency of $N$ utilization}

In the first year after compost application, we found the efficiency of compost $\mathrm{N}$ utilization to be $5-12 \%$ in the conventional and $2-8 \%$ in the organic experiment. These $\mathrm{N}$ recoveries were close to the overall range of 5-15\% with various composts during the application year presented by Amlinger et al. (2003) in their review. Increasing the amount of inorganic $\mathrm{N}$ applied in composts is likely to increase the $\mathrm{N}$ recovery (Svensson et al. 2004), as inorganic $\mathrm{N}$ is directly available to plants whereas the rest of compost $\mathrm{N}$ is available to plants only after mineralization. Eghball and Power (1999a) considered the $\mathrm{N}$ availability of $20 \%$ from composted feedlot manure to be lower than expected, whereas from uncomposted manure they estimated a $38 \% \mathrm{~N}$ availability during the first year. In their study, part of the low $\mathrm{N}$ availability may have been caused by the lower amount of inorganic $\mathrm{N}$ applied in compost than in uncomposted manure, but apart from that application in autumn may have decreased the $\mathrm{N}$ availablity. The $\mathrm{N}$ available from composts has been clearly lower than that from mineral fertilizer (Zheljazkov et al. 2006), although the crop $N$ recovery may underestimate the mineralization from organic amendments (Lynch et al. 2004). Accordingly, our $\mathrm{N}$ recoveries less than $12 \%$ with composts were consistently lower than the over $50 \% \mathrm{~N}$ recovery with Mineral fertilization.

Similarly to Iglesias-Jimenez and Alvarez (1993), we found a trend of highest $\mathrm{N}$ efficiencies with the lowest compost applications in the first year. This was due to only slightly increased, but not doubled ANU with doubled $\mathrm{N}$ addition in high compost fertilization. The higher $\mathrm{N}$ recovery in the grass experiment compared with the grass-clover experiment was caused by different crops, as the $\mathrm{N}$ uptake of barley-grass was higher than that of barley nurse crop. We determined the dosage of composts on the basis of categorical assumption of $P$ fertilization effect of composts, which in most cases led to total $\mathrm{N}$ amounts exceeding the limit of the EU nitrate directive (Council of State 931/2000). If the upper limit of $250 \mathrm{~kg}$ total $\mathrm{N} \mathrm{ha}^{-1}$ for silage crops had been followed in the grass experiment, it would have been possible to apply 90, 61, 46 and $30 \%$ of the amounts of Biowaste ${ }_{\text {low }}$, BioSludge $_{\text {low }}$, Biowaste $_{\text {high }}$ and BioSludge ${ }_{\text {high, }}$, respectively. In that case, the amount of nutrients supplied into soil would have decreased correspondingly and the yields could probably have been lower during the first year.

The $\mathrm{N}$ recovery for biannually applied feedlot manure compost has been estimated to decrease from $15 \%$ in the application year to $8 \%$ in the second year in corn production (Eghball and Power 1999b). Accordingly, we found decreasing compost $\mathrm{N}$ recovery in the organic experiment from the 


\section{AGRICULTURAL AND FOOD SCIENCE}

Tontti, T. et al. Waste composts as fertilizers

first to the second year, although in our experiments the harvested crops varied between those years. From the second to the third year the $\mathrm{N}$ recovery in grass of the organic ley generally increased due to increased ANU in the compost-fertilized grass. In the conventional grass ley the increase of compost $\mathrm{N}$ recovery from the first to the second year was probably due to supplemental mineral fertilization, whereas the decrease from the second to the third year was mostly due to increased $\mathrm{N}$ uptake in the unfertilized grass ley.

The efficiency of compost $\mathrm{N}$ utilization has been estimated often as an average $\mathrm{N}$ recovery over a multi-year period where compost has been applied once in two years or with variable frequency (Eghball and Power 1999b, Hartl and Erhart 2005). However, the multi-year approach does not show possible changes between or within years. Lynch et al. (2004) estimated the fertilizer $\mathrm{N}$ recovery at the level of forage cuts, presenting the difference of $\mathrm{N}$ uptake in fertilized and unfertilized crop (which is equivalent to $\mathrm{ANU}$ ) in proportion to the cumulative amount of total $\mathrm{N}$ applied before that cut. Correspondingly, we assumed that previous total $\mathrm{N}$ additions in fertilizer into the soil were included in the $\mathrm{N}$ supply for plants, but apart from that we subtracted the previous plant ANUs from the total fertilizer N supply. Lynch et al. (2004) found that in the year following the last compost fertilization of timothy forage the $\mathrm{N}$ recoveries ranged from slightly immobilized $(-1 \%)$ up to $8 \%$. In the second and third year in the organic grass-clover ley, we found nearly the same range of $\mathrm{N}$ recovery in grass, from $-7 \%$ up to $8 \%$. Due to annual mineral $\mathrm{N}$ additions our $\mathrm{N}$ recoveries in the conventional grass ley were clearly higher, up to $42 \%$ in the second year and $28 \%$ in the third year.

Basically, we used the estimated BNF in the organic grass-clover ley as $\mathrm{N}$ input in the $\mathrm{N}$ recovery estimations for the second and third experimental year. Because the estimated BNF was, in fact, equal to the clover $\mathrm{N}$ uptake, we reduced both BNF and clover $\mathrm{N}$ uptake from the $\mathrm{N}$ recovery estimation. In case we had measured BNF directly, for example by the $\mathrm{N}^{15}$ method (Sikora and Enkiri 2001), the accurate BNF might have been lower than the clover $\mathrm{N}$ uptake. In that case, the estimate of compost
$\mathrm{N}$ recovery in grass-clover ley might have been higher, because part of clover $\mathrm{N}$ would have originated from the composts. The transfer of cloverfixed $\mathrm{N}$ to grasses is difficult to quantify and clover $\mathrm{N}$ mostly releases to the soil only after ploughing of ley (Hoegh-Jensen 2006, Hakala and Jauhiainen 2007). Therefore, considering the BNF as an immediate $\mathrm{N}$ input to the soil during the ongoing growing period might have been inaccurate.

The NUE over three years was highest with low total $\mathrm{N}$ inputs and inversely proportional to the $\mathrm{N}$ balance values. Accordingly, in previous results of organic cereals fertilized with incorporation of grass-clover ley into the soil, the lowest NUEs were found with higher $\mathrm{N}$ input or lower $\mathrm{N}$ uptake (Nykänen 2008).

The utilization and efficiency of fertilizer $\mathrm{N}$ may be assessed by various methods, but the different scopes and boundaries of these methods should be clarified, particularly when organic fertilizers are considered. The estimates of $\mathrm{N}$ balance and NUE could be appropriate for assessing the utilization of $\mathrm{N}$ in a certain cropping system over several years. When the utilization of fertilizer $\mathrm{N}$ should be separated from the background effect of that particular soil, the estimate of ANU could be applied. The ANUs may be calculated annually or more frequently and a certain fertilization can be compared between various locations. The estimates for efficiency of $\mathrm{N}$ utilization, for example $\mathrm{N}$ recovery, clarify the effect of fertilizer $\mathrm{N}$ in relation to the amount of total $\mathrm{N}$ in the fertilizer and allow comparisons between various fertilizers in variable conditions. However, the $\mathrm{N}$ recovery of organic fertilizers might be underestimated, while the $\mathrm{N}$ recovery of mineral fertilizers is typically high.

\section{Conclusions}

In mature municipal waste composts the majority of total $\mathrm{N}$ is in organic form leaving less than $10 \%$ as inorganic N. Yield response and the efficiency of $\mathrm{N}$ utilization during the application year increase with increasing supply of inorganic $\mathrm{N}$ in compost, 


\section{AGRICULTURAL AND FOOD SCIENCE}

Vol. 18 (2009): 57-75.

whereas a high amount of total $\mathrm{N}$ alone might not give yield responses. The recovery of compost $\mathrm{N}$ is usually much lower than that of mineral fertilization, with maximum recovery of $12 \%$ in the present study. In organic grass-clover ley established with waste composts the $\mathrm{N}$ recovery may be close to that with manure compost. In the organic ley, increase of clover yield may compensate for low grass yield, whereas high supply of inorganic $\mathrm{N}$ might be unfavourable for clover.

Single application of compost with less than 25 $\mathrm{Mg} \mathrm{ha}^{-1}$ may produce equal yields and $\mathrm{N}$ uptakes as doubled amounts of composts. Furthermore, based on $\mathrm{N}$ balance and estimates of $\mathrm{N}$ use efficiency, smaller applications of composts are most suitable for both conventional and organic ley in the long run. Waste composts may be supplemented with either moderate inorganic $\mathrm{N}$ additions or $\mathrm{N}$ fixation of clover. However, the optimal level of compost application and supplemental fertilization is casespecific, varying according to the characteristics of the compost and crop in question. The various estimates describing utilization of $\mathrm{N}$ should be interpreted with consideration of the scopes and boundaries of these methods. Moreover, a substantial part of compost $\mathrm{N}$ may be released only after the application year and, therefore, the annual estimation of $\mathrm{N}$ efficiency in the following years should include the residual of the previously added, unused total $\mathrm{N}$.

Acknowledgements. The experimental work was funded by the Finnish Ministry of Agriculture and Forestry, the Finnish Ministry of the Environment and MTT Agrifood Research Finland. We sincerely thank all the persons involved in the field and laboratory work conducted at MTT Agrifood Research Finland, and especially Keijo Lehtonen, D.Sc. (Chem.), for his valuable contribution to this work and biometricians Timo Hurme and Lauri Jauhiainen for their advice in the statistical analyses of the data. We also thank Assistant Professor Kari Hänninen (University of Jyväskylä, Environmental Science) for useful comments during the preparation of this paper, Sevastiana Ruusamo, M.A., for revision of the English manuscript and all other associates for their invaluable contributions to the revisions of this manuscript. The preparation of this paper was financially supported by the Finnish Graduate School for Environmental Science and Technology (EnSTe) and the Finnish Cultural Foundation.

\section{References}

Agricultural Research Centre of Finland 1986. Soil and Plant Analysis. Agricultural Research Centre, Department of Soil Science. Jokioinen, Finland: 45 p.

Amlinger, F., Götz, B., Dreher, P., Geszti, J. \& Weissteiner, C. 2003. Nitrogen in biowaste and yard waste compost: dynamics of mobilisation and availability-a review. European Journal of Soil Biology 39: 107-116.

Antikainen, R., Lemola, R., Nousiainen, J.I., Sokka, L., Esala, M., Huhtanen, P. \& Rekolainen, S. 2005. Stocks and flows of nitrogen and phosphorus in the Finnish food production and consumption system. Agriculture, Ecosystems \& Environment 107: 287-305.

Boller, B.C. \& Nösberger, J. 1987. Symbiotically fixed nitrogen from field- grown white and red clover mixed with ryegrasses at low levels of ${ }^{15} \mathrm{~N}$-fertilization. Plant and Soil 104: 219-226.

Cassman, K.G., Dobermann, A. \& Walters, D.T. 2002. Agroecosystems, nitrogen-use efficiency, and nitrogen management. Ambio 31: 132-140.

Council of State 931/2000. Government Decree on the restriction of discharge of nitrates from agriculture into waters. Original in Finnish: Valtioneuvoston asetus maataloudesta peräisin olevien nitraattien vesiin pääsyn rajoittamisesta. Translation available in English at Internet: http://www.finlex.fi/en/laki/kaannokset/2000/ en20000931.pdf (Cited 20.12.2007).

Debosz, K., Petersen, S.O., Kure, L.K. \& Ambus, P. 2002. Evaluating effects of sewage sludge and household compost on soil physical, chemical and microbiological properties. Applied Soil Ecology 19: 237-248.

Eghball, B. \& Power, J.F. 1999a. Composted and noncomposted manure application to conventional and no-tillage systems: corn yield and nitrogen uptake. Agronomy Journal 91: 819-825.

Eghball, B. \& Power, J.F. 1999b. Phosphorus- and nitrogen-based manure and compost applications: Corn production and soil phosphorus. Soil Science Society of America Journal 63: 895-901.

Epstein, E. 1997. The Science of Composting. Lancaster, Basel: Technomic Publishing. 482 p.

Erhart, E., Hartl, W. \& Putz, B. 2005. Biowaste compost affects yield, nitrogen supply during the vegetation period and crop quality of agricultural crops. European Journal of Agronomy 23: 305-314.

Fauci, M.F. \& Dick, R.P. 1994. Plant response to organic amendments and decreasing inorganic nitrogen rates in soils from a long-term experiment. Soil Science Society of America Journal 58: 134-138.

Gabrielle, B., Da-Silveira, J., Houot, S. \& Michelin, J. 2005. Field-scale modelling of carbon and nitrogen dynamics in soils amended with urban waste composts. Agriculture, Ecosystems \& Environment 110: 289-299.

Gagnon, B., Simard, R.R., Robitaille, R., Goulet, M. \& Rioux, R. 1997. Effect of composts and inorganic fertilizers on spring wheat growth and $\mathrm{N}$ uptake. Canadian Journal of Soil Science 77: 487-495.

Hakala, K. \& Jauhiainen, L. 2007. Yield and nitrogen concentration of above- and below-ground biomasses of 


\title{
AGRICULTURAL AND FOOD SCIENCE
}

\author{
Tontti, T. et al. Waste composts as fertilizers
}

red clover cultivars in pure stands and in mixtures with three grass species in northern Europe. Grass and Forage Science 62: 312-321.

Hänninen, K., Koivula, N., Miikki, V., Urpilainen, S. \& Räikkönen, T. 2001. Source separation and composting of biowaste with a view to recycling of the end product. Jyväskylän yliopiston biologian laitoksen tiedonantoja 73. 29 p.

Hänninen, K. \& Mäkelä-Kurtto, R. 1995. Erilliskerätyn biojätteen aumakompostointi ja kompostin käyttökelpoisuus. Pääkaupunkiseudun julkaisusarja C 1995:17. $57 \mathrm{p}$.

Hartl, W. \& Erhart, E. 2005. Crop nitrogen recovery and soil nitrogen dynamics in a 10-year field experiment with biowaste compost. Journal of Plant Nutrition and Soil Science 168: 781-788.

Hoegh-Jensen, H. 2006. The nitrogen transfer between plants: An important but difficult flux to quantify. Plant and Soil 282: 1-5.

Houot, S., Clergeot, D., Michelin, J., Francou, C., Bourgeois, S., Caria, G. \& Ciesielski, H. 2002. Agronomic value and environmental impacts of urban composts used in agriculture. In: Insam, $\mathrm{H}$. et al. (eds.) Microbio/ogy of Composting. Berlin Heidelberg New York: Springer-Verlag. p. 457-472.

Iglesias-Jimenez, E. \& Alvarez, C.E. 1993. Apparent availability of nitrogen in composted municipal refuse. Biology and Fertility of Soils 16: 313-318.

Jakobsen, S.T. 1995. Aerobic decomposition of organic wastes 2. Value of compost as a fertilizer. Resources, Conservation and Recycling 13: 57-71.

Jokinen, R. 1990. Effect of phosphorus precipitation chemicals on characteristics and agricultural value of municipal sewage sludges: 1 . Characteristics of $\mathrm{Ca}, \mathrm{Al}$ and Fe precipitated sewage sludges. Acta Agriculturae Scandinavica 40: 123-129.

Keeling, A.A., McCallum, K.R. \& Beckwith, C.P. 2003. Mature green waste compost enhances growth and nitrogen uptake in wheat (Triticum aestivum L.) and oilseed rape (Brassica napus L.) through the action of water-extractable factors. Bioresource Technology 90: 127-132.

Kenward, M.G. \& Roger, J.H. 1997. Small sample inference for fixed effects from restricted maximum likelihood. Biometrics 53: 983-997.

Koivula, N., Hänninen, K.I. \& Tolvanen, O.K. 2000. Windrow composting of source separated kitchen biowastes in Finland. Waste Management \& Research 18: 160-173.

Littell, R.C., Milliken, G.A., Stroup, W.W., Wolfinger, R.D., \& Schabenberger, O. 2006. SAS for Mixed Models, Second Edition. Cary, NC: SAS Institute Inc. 814 p.

Lynch, D.H., Warman, P.R. \& Voroney, R.P. 2004. Nitrogen availability from composts for humid region perennial grass and legume-grass forage production. Journal of Environmental Quality 33: 1509-1520.

Mamo, M., Rosen, C.J. \& Halbach, T.R. 1999. Nitrogen availability and leaching from soil amended with municipal solid waste compost. Journal of Environmental Quality 28: 1074-1082.

Mulvaney, R.L. 1996. Extraction of exchangeable ammonium and nitrate. In: Sparks, D.L. (ed.). Methods of Soil Analysis: Part 3. Madison, Wisconsin: Soil Science
Society of America and American Society of Agronomy. p. 1129-1131.

Nykänen, A. 2008. Nitrogen dynamics of organic farming in crop rotation based on red clover (Trifolium pratense) leys. Agrifood Research Reports 121: 60 p. +4 app. Diss.: University of Helsinki, 2008. (Doctoral Dissertation). Available at internet: http://www.mtt.fi/met/ pdf/met121.pdf (Updated 15.4.2008)

Nykänen, A., Granstedt, A., Laine, A. \& Kunttu, S. 2000. Yields and clover contents of leys of different ages in organic farming in Finland. Biological Agriculture \& Horticulture 18: 55-66.

Nykänen, A., Jauhiainen, L., Kemppainen, J. \& Lindström, K. 2008. Field-scale spatial variation in soil nutrients and in yields and nitrogen fixation of clover-grass leys. Agricultural and Food Science 17: 376-393.

Rantala, P.R., Vaajasaari, K., Juvonen, R., Schultz, E., Joutti, A. \& Mäkelä-Kurtto, R. 1999. Composting of forest industry wastewater sludges for agricultural use. Water Science and Technology 40: 187-194.

Sikora, L.J. \& Enkiri, N.K. 1999. Fescue growth as affected by municipal compost fertilizer blends. Compost Science \& Utilization 7: 63-69.

Sikora, L.J. \& Enkiri, N.K. 2001. Uptake of $15 \mathrm{~N}$ fertilizer in compost-amended soils. Plant and Soil 235: 65-73.

Smith, S.R., Woods, V. \& Evans, T.D. 1998. Nitrate dynamics in biosolids-treated soils. II. Thermal-time models of the different nitrogen pools. Bioresource Technology 66: 151-160.

Stratton, M.L., Barker, A.V. \& Rechcigl, J.E. 1995. Compost. In: Rechcigl, J.E. (ed.). Soil amendments and environmental quality. Boca Raton, New York, London, Tokyo: CRC, Lewis Publishers. p. 249-309.

Sullivan, D.M., Bary, A.I., Thomas, D.R., Fransen, S.C. \& Cogger, C.G. 2002. Food waste compost effects on fertilizer nitrogen efficiency, available nitrogen, and tall fescue yield. Soil Science Society of America Journal 66: 154-161.

Svensson, K., Pell, M. \& Odlare, M. 2004. The fertilizing effect of compost and biogas residues from source separated household waste. Journal of Agricultural Science 142: 461-467.

Tognetti, C., Mazzarino, M. \& Laos, F. 2007. Cocomposting biosolids and municipal organic waste: effects of process management on stabilization and quality. Biology and Fertility of Soils 43: 387-397.

Väisänen, J. 2000. Biological nitrogen fixation in organic and conventional grass-clover swards and a model for its estimation. University of Helsinki, Department of Plant Production. Licentiate's thesis. $42 p+2$ app.

Väisänen, J., Nykänen, A. \& Granstedt, A. 2000. Estimation of biological nitrogen fixation in Finnish organic grasslands. Grassland Science in Europe 5: 530-532.

Venelampi, O., Weber, A., Rönkkö, T. \& Itävaara, M. 2003. The biodegradation and disintegration of paper products in the composting environment. Compost Science \& Utilization 11: 200-209.

Watson, C.A., Bengtsson, H., Ebbesvik, M., Løes, A., Myrbeck, A., Salomon, E., Schroder, J. \& Stockdale, E.A. 2002. A review of farm-scale nutrient budgets for organic farms as a tool for management of soil fertility. Soil Use and Management 18: 264-273. 
Vol. 18 (2009): 57-75.

Westerman, P.W. \& Bicudo, J.R. 2005. Management considerations for organic waste use in agriculture. Bioresource Technology 96: 215-221.

Zheljazkov, V.D., Astatkie, T., Caldwell, C.D., MacLeod,
J. \& Grimmett, M. 2006. Compost, manure, and gypsum application to timothy/red clover forage. Journal of Environmental Quality 35: 2410-2418.

\title{
SELOSTUS
}

\section{Jätekompostit rehunurmen lannoitteena}

\author{
Tiina Tontti, Arja Nykänen ja Miia Kuisma \\ Maa- ja elintarviketalouden tutkimuskeskus
}

Heinänurmi ja apila-heinänurmi perustettiin suojaviljaan keväällä 2000 ja lannoitettiin perustamisvaiheessa biojätekompostin tai biojäte-puhdistamolietekompostin kahdella eri tasolla. Tavanomaisella heinänurmella verrannelannoitteena käytettiin väkilannoitetta ja luonnonmukaisella apila-heinänurmella käytettiin karjanlantakompostia. Suojaviljasta ja nurmista mitattiin sadot, typpisadot sekä maan liukoisen typen $\left(\mathrm{NH}_{4}, \mathrm{NO}_{3}\right)$ pitoisuudet vuosina 2000-2002. Lisäksi apila-heinänurmen apilasadon avulla määritettiin biologisen typensidonnan määrä. Toisen ja kolmannen vuoden aikana tavanomaiselle heinänurmelle annettiin typen ja kaliumin lisälannoitus lannoitussuosituksen mukaisesti. Typen hyödyntämisen tehokkuutta arvioitiin vuosittain kahdella menetelmällä, typen hyväksikäyttöasteen ( $N$ recovery) ja kasvien saatavilla olevan typen määrän $(\mathrm{ABN})$ arvioinnin avulla. Typen hyödyntämistä kolmivuotisen jakson aikana arvioitiin typen peltotaseen ( $\mathrm{N}$ balance) ja typen käytön tehokkuuden (NUE) avulla.

Kompostien kokonaistypestä alle $10 \%$ oli liukoisessa muodossa ja kompostitypen hyväksikäyttöaste ensimmäisen vuoden kasvisatoon vastasi suurimmillaankin biojätekompostilannoituksella alle 12\% kompostien kokonaistypestä. Suojaviljan kuiva-aine- ja typpisato sekä typen hyväksikäyttöaste kasvoivat kompostilan- noituksessa annetun liukoisen typpimäärän kasvaessa ja kompostikäsittelyt lisäsivät satoja lannoittamattomaan kontrolliin verrattuna. Toisen ja kolmannen koevuoden aikana biojätekompostilla lannoitetun apila-heinänurmen sato oli alhaisempi kuin lantakompostilannoituksella. Toisaalta biojäte-puhdistamolietekompostilla lannoitetun seosnurmen apilasato oli suurempi ja kokonaissato yhtä suuri kuin lantakompostilannoituksella. Ensimmäisen vuoden alhaisella kokonaistyppilannoituksella typen hyväksikäyttöaste toisen ja kolmannen vuoden aikana saattoi olla suurempi ja vuotuinen sadontuotto yhtä suuri kuin suuremmalla kompostilannoituksella. Kolmen vuoden typpitaseet olivat yleensä positiivisia ja joissakin tapauksissa hyvinkin suuria, sillä kompostilannoituksissa annettiin suuri määrä orgaanista kokonaistyppeä josta vain osa korjattiin kasvuston typpisadossa. Typpitase oli positiivinen ja lähinnä tasapainotilannetta alhaisella lannoitustasolla sekä biojätekompostilannoituksella. Typen käytön tehokkuus (NUE) oli kääntäen verrannollinen typpitaseisiin, sillä pienemmällä kompostilannoituksen määrällä saatiin suurempi typen käytön tehokkuus ja likimain sama typpisato kuin suuremmalla kompostilannoituksella. Jätekomposteja voi käyttää rehunurmen lannoitukseen ja täydentää kompostilannoitusta väkilannoitteella tai apilan typensidonnan avulla. 